\title{
Catching Technology of Fish Maw Snapper's: Case Study of the KMN Nur Aqila07 Fishing Boat in Kumbe Village, Malind District, Merauke Regency, Papua
}

\author{
Sajriawati Sajriawati * \\ Department of Aquatic Resources Management, Faculty of Agriculture, Universitas Musamus, Merauke, Indonesia
}

\begin{abstract}
The purpose of this study was to determine the fishing technology used by fishermen in Merauke to catch snapper and post-harvest handling of fish maw snapper. This research was conducted in January 2021 in Kumbe Village, Malind District. Data collection was carried out by interviewing fishermen on the fishing boat KMN Nur Aqila07. The results showed that the fishing boat KMN Nur Aqila07 has a weight specification of 30 GT. The main fishing gear is a drift gill net with a length of 50 meters with a width of 2 meters with a mesh size of 7.5 inches. The pulley machine is used to help pull the gill nets when they want to pull fishing gear (hauling). Fish maw of snapper is removed manually using a knife, then cleaned with running water and then dried in the sun to dry. Fish maw is sold dry. The highest price for fish maw is in the weight range of 150 grams which can reach Rp. 22,500,000 per kg, while the lowest price is in the weight range of less than 50 grams, which is $\mathrm{Rp} .4,500,000$ per $\mathrm{kg}$.
\end{abstract}

Keywords: Catching Technology, Fish Maw Snapper's, KMN Nur Aqila07, Merauke

\section{Introduction}

Merauke Regency is one of the districts in the Papua province that has the potential for rich marine fishery resources sourced from the waters of the Arafura Sea. The fisheries potentials in the Arafura Sea include pelagic (anchovies, mackerel, and mackerel), demersal (snapper, pomfret and ray), shrimp, squid, grouper to ornamental fish. No wonder the area is an attraction for fishing vessels both from the Merauke area, outside Merauke and some even from abroad [1]. One of the demersal fish that is the main target of fishermen in Merauke is the snapper fish. Snapper is a type of fish that lives on the bottom of a coral or coral reef area and lives in groups. The snapper has a body characteristic that is round and flat with fins extending along the back [2]. The type of snapper caught in Merauke is the white snapper. The maximum sustainable catch (MSY) based on the Fox model in the Kumbe River, Malind District is $212.763 \mathrm{~kg}$ with an optimal catch effort (Fopt) of 33.783 hauling. The potential value of white snapper in the Kumbe River has not exceeded the MSY (underfishing) value so it is still possible to increase its catch [3]. The snapper caught is usually only targeted by the swim bladder, while the fish meat is only used as dried fish. Fish bubble in international language is known as Fish Maw. Fish maw are fish organs that help fish float in the water. The snapper swim bubble has a very high economic price. This is because the fish maw is exported abroad and the demand is quite high. The country that consumes a lot of fish maw and is the biggest export destination is China. These fish maw are usually processed into food ingredients such as soup, apart from the information obtained from collectors, these fish maw are also used as material for making surgical threads. The number of shipments of dried fish maw from Merauke Regency is quite large, data from SKIPM Merauke shows that in 2018 alone, from January to June the number of fish bubble shipments from Merauke reached 82,000 kilograms [4]. The price of bubble fish varies. One of the factors that need to be taken into account when selling fish maw is the sex of the fish. The difference in the sex of the fish will also affect the price of the fish maw. Apart from that, the difference in weight also affects the price of the bubble. Before being sold, the fish maw are grouped by weight per gram. The difference in weight per gram makes the difference in the selling price of fish maw [5].

The technology of snapper fishing in Merauke is interesting to research, considering that the area for catching snapper is in the Arafura Sea which is quite far from the coastline so that it takes a long time to catch. Fishermen usually catch about 14 to 40 days depending on supplies and the size of the boat. Based on the foregoing, research was carried out on the technology of catching snapper fish maw by fishermen in Kumbe village, Malind District, Merauke. This study aims to determine what types of fishing gear the fishermen use

\footnotetext{
* Corresponding author: sajriawati_msp@unmus.ac.id
} 
and how to handle post-harvest snapper fish maw before they are sold.

\section{Methodology}

This research was conducted in Kumbe Village, Malind District, Merauke Regency in January 2021. The research method used was the interview method with direct observation techniques. The research object is the owner of the ship KMN Nur Aqila07, the captain of the ship and the crew. The data used are primary data with data analysis techniques, namely descriptive.

\section{Result and Discussion}

The snapper fishing technology in Merauke uses drift gill nets as fishing gear, a motor boat, and a net towing machine. The fishing motor boat used has been registered under the name KMN Nur Aqila07 and has a fishing license (SIPI). KMN Nur Aqila07 (Figure 1) has a weight of 30 GT with a size of $20 \times 5$ meters. This ship began operating since 2018 in November.

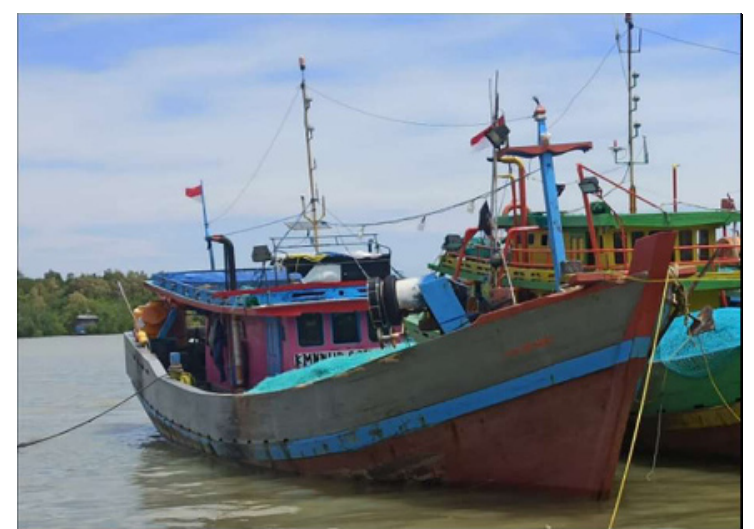

Fig. 1. Ship KMN Nur Aqila07

Based on the regulations of the Ministry of Maritime Affairs and Fisheries, ships weighing $30 \mathrm{GT}$ and above are required to have a Fishing Permit (SIPI), so as a rule, KMN Nur Aqila07 has complied with the applicable regulations [6].

The KMN Nur Aqila07 ship was piloted by a captain and 6 crew members. The maximum number of crew on this ship can be up to 7 crew members. Determination of the maximum number of crew members is to pay attention to the work safety system. Another thing that must be considered is the problem of safety equipment in ships. Safety devices are equipment that has a construction or material that has specifications that can help protect, prevent and stop work accidents on board. The existence of safety devices on fishing boats is based on the size of the ship, especially in relation to the number, size and suitability of the equipment [7]. The KMN Nur Aqila07 ship is equipped with several safety devices such as GPS, SSB radio, compass, life jacket, life jacket, glasses, one hand, work shoes, crane, tools, and first aid kit. According to [8], Nelayan already understands the importance of work safety equipment, it's just that the availability and number of work safety equipment on board are inadequate.

The fishing rod used on this ship is the gill net catching tool (Figure 2) with a net length of 50 meters and a width of 2 meters. The mesh size used is 7.5 inches. Pala and Yuksel [9] explain that the size of the gill mesh has a significant effect on the efficiency and composition of the catch. Gill nets drifting operated at night day with a water depth of 10-15 m. This condition causes other types of commercial fish, such as snapper to be caught [10].

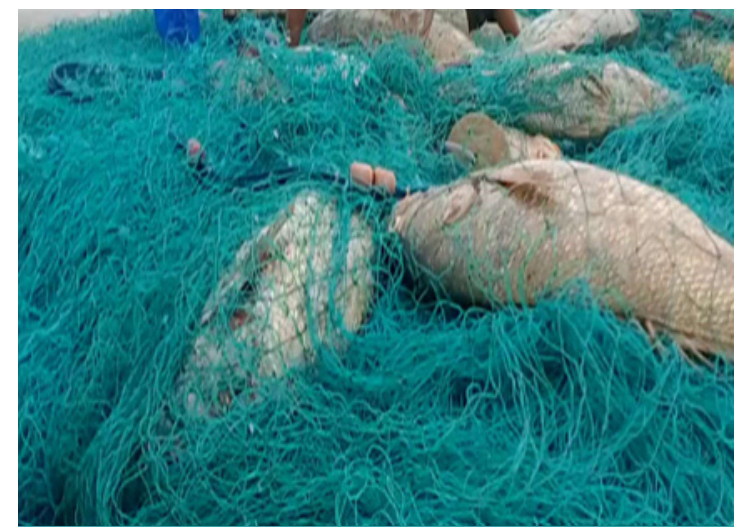

Fig. 2. Drifting Gill Nets

Drift gill nets are among the oldest and simplest fishing gear. The method of action is by trapping fish. The lower part of the net is tied with a ballast while the top is equipped with a float. These nets can be operated either by ship or without a fishing gear fleet [11]. According to Martasuganda [12], drifting gill nets are operated by allowing them to drift in the water. Drift gill nets can be washed off the bottom of the water, in the water column, or on the surface.

After the washed net has caught the fish, the next process is to pull the net. Because the size of the net is quite long and large, it cannot be done manually by human labor. The withdrawal of the nets is assisted by the net hauler (Figure 3), which is a fishing aid on the gill net which is used to pull the nets that have been sown in the sea, so that the nets are lighter and easier to pull back on the deck.

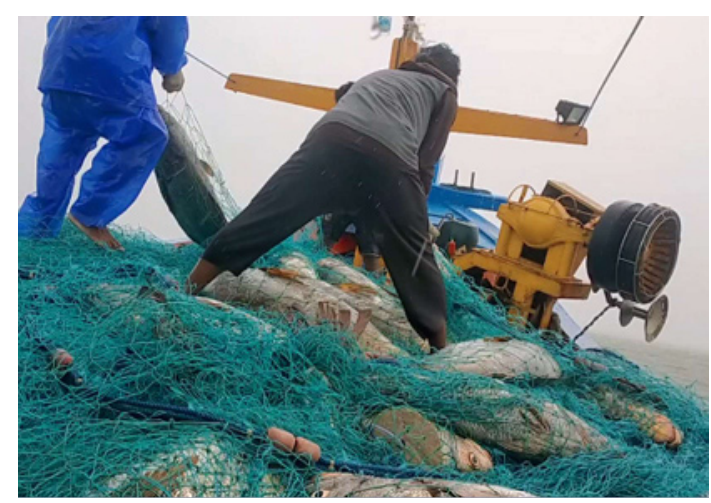

Fig. 3. Pulling Machine 
This net pulling machine is placed on the working deck on the side of the hauling direction, to pull the net during hauling, the ballast, float and net are inserted into a rotating block (roller) driven by hydraulic power.

After the net withdrawal process is complete, the next step is handling the post-harvest fish. The snapper caught is actually only targeted by the fish maw. This is because the snapper fish maw have a very high selling price. The price of Chinese snapper fish maw has a price variation based on weight. The highest price is in the 150 gram weight range, which can reach Rp. 22,500,000 per $\mathrm{kg}$, while the lowest price is in the weight range of less than 50 grams, namely Rp. 4,500,000 per $\mathrm{kg}$. Meanwhile, the fish meat will only be made into salted fish with a selling price of Rp. 25,000 per kg.

The snapper that has been caught is immediately removed from the net (Figure 4) and the swim bladder is subsequently removed (Figure 5).

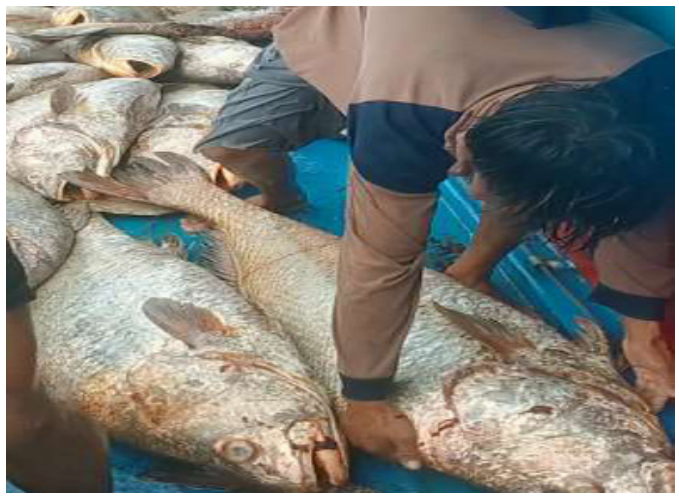

Fig. 4. Snapper taken out from the net

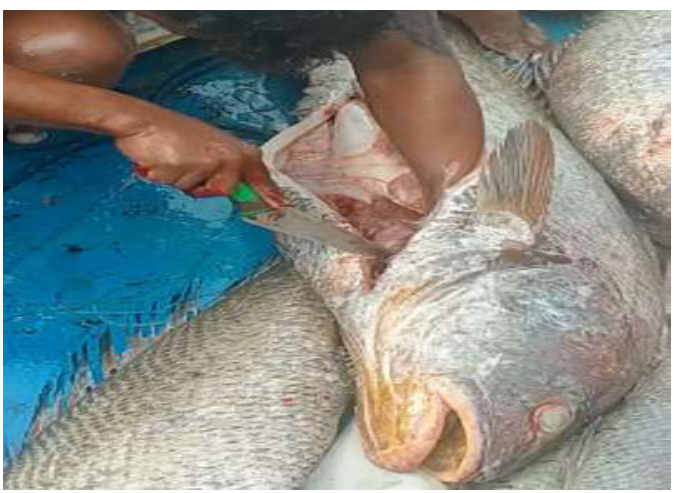

Fig. 5. The process of releasing fish maw from snapper

The snapper fish maw are removed manually using a kitchen knife. The process of removing the fish fish maw must be done carefully so as not to damage the bubble structure of the fish.

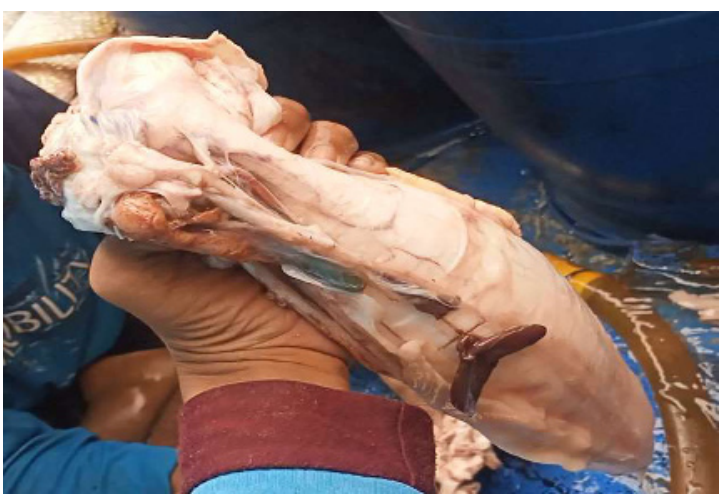

Fig. 6. The snapper fish maw are still wet

After the fish maw are removed from the fish's body (Figure 6), the next process is to clean the fish maw with running water

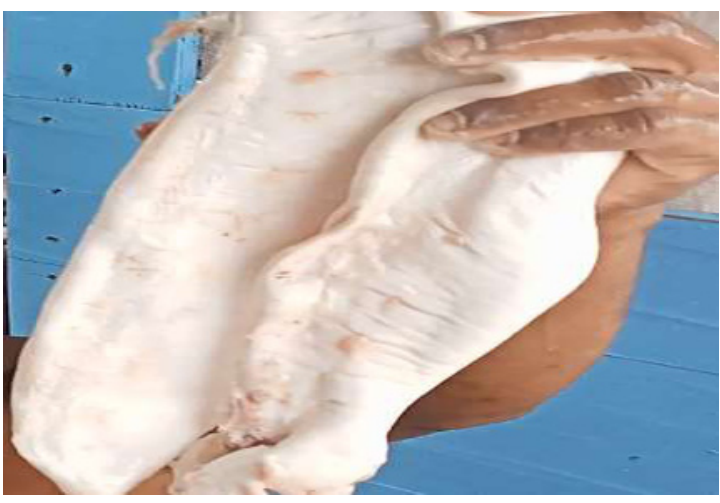

Fig. 7. Fish maw that have been clean

The last step is drying the clean fish maw. Fish maw are sold dry. Fish maw sales are made on land after the ship returns from fishing. The dried fish maw will be sold to collectors or collectors which are then sent to Jakarta for export abroad.

\section{Conclusion}

The fishermen in Kumbe Village, Malind Merauke District, catch snapper fish maw using drift nets as the main fishing gear, a boat and a net pulling machine. KMN Nur Aqila07 has a ship weight of 30 GT with 2 main engines from the Mitsubishi brand. The drift gill nets used have a length of 50 meters by a width of 2 meters with a mesh size of 7.5 inches. The pulley machine is used to help pull the gill nets when they are about to pull the fishing gear (hauling). The arrest was carried out by 6 crew members (crew members of the ship) as well as a ship captain. The captured snapper fish maw are removed manually using a knife, then cleaned with running water and then dried in the sun to dry. The snapper fish maw is sold dry. The price of Chinese snapper bubble has a price variation based on weight. The highest price is in the 150 gram weight range, which can reach Rp. 22,500,000 per kg, while the lowest price is in the weight range of less than 50 grams, namely Rp. $4,500,000$ per $\mathrm{kg}$. out title. 


\section{References}

1. Perum Perindo, "Gali Peluang Ekspor Perikanan dari Laut Arafura," [online] https://www.perumperindo.co.id/publikasi/berita, vol. . [online], (2021).

2. Wikipedia, "Kakap," [online] https://id.wikipedia.org/wiki/Kakap, 2021.

3. Edy HP. Melmambessy and S. M. Mohamad Hari Widodo , , "Potensi Ikan Kakap Putih (Lates calcarifer Bloch, 1790) di Sungai Kumbe Distrik Malind Kabupaten Merauke," J. Agric., vol. 6, no. 1, pp. 31-39, (2016).

4. Kementerian Kelautan dan Perikanan, "Bisnis Plan SKPT Merauke," https://kkp.go.id/SKPT/Merauke/page/1149bisnis-plan-skpt-merauke, p. downloaded on January 20, 2020 (2018).

5. Sajriawati, "Variasi Harga Jual Gelembung Ikan oleh Nelayan Lampu Satu di Kabupaten Merauke," Musamus J. Agribus., vol. 3, no. 1, pp. 46-52, (2020).

6. Hanz Jimenez Salim, "Jokowi: Kapal Nelayan di Bawah 10 GT Tidak Perlu Izin.," [online] https://www.liputan6.com/cekfakta/read/3897470/cek-fakta-jokowi-kapalnelayan-di- bawah-10-gt-tidak-perlu-izin, (2019).

7. Fis Purwangka and B. H. I. Adi Guna Santara, , "Safety Equipment on Slerek in Pengambengan Nusantara Fishing Port, Jembrana, Regency, Bali," J. IPTEKS PSP ISSN 2355-729X, vol. 1, no. April, pp. 53-68, (2014).

8. Riki Rinaldi, "Kajian Keselamatan Kerja Nelayan Purse Seine Di Pelabuhan Perikanan Samudera (Pps) Kutaraja, Banda Aceh.," Univ. Syiah Kuala, Banda Aceh, (2019).

9. Y. M. Pala M, "Comparison of the catching efficiency of monofilamen gillnet with different mesh size," J. Anim. Vet. Adv., vol. 7, pp. $1146-$ 1149., (2010).

10. Ali Rahantan dan Gondo Puspito, "Appropriate of Mesh Size and Shortening for Gillnet Operated on Tual Waters," J. Mar. Fish., vol. 3, no. 2, pp. 141147, (2012).

11. S. P. Northridge., "Driftnet fisheries and their impacts on non-target species: a worldwide review. FAO," FAO, (1991).

12. S. Martasuganda, "Jaring Insang (Gillnet). Departemen Pemanfaatan Sumberdaya Perikanan dan Pusat Kajian Sumberdaya Pesisir dan Lautan," nstitut Pertan. Bogor. Bogor., (2008). 